\title{
Impact of the exploitation of medicinal plants on biodiversity conservation in Saida and El Bayadh regions, Algeria
}

\author{
Yahia Nasrallah $^{1 *}$, Sid Ahmed Aouadj ${ }^{2} \&$ Hadj Khatir ${ }^{3}$
}

${ }^{1}$ Laboratory of Biotoxicology, Pharmacognosia and Biological Valuation of Plants, Department of Biology, Faculty of Sciences, Dr Tahar Moulay University of Saida, Algeria; ORCID: https://orcid.org/0000-0003-1134-2623

${ }^{2}$ Laboratory of Ecology and Management of Natural Ecosystems, Department of Ecology and Environment, Faculty of Nature and Life Sciences and Earth and Universe Sciences, Abou Bakr Belkaid University, Tlemcen, Algeria; ORCID: https://orcid.org/0000-0001-8754-4286 ${ }^{3}$ Private scientific consultant and a head of Reprodbiotech and stem cells. Montréal, Canada; ORCID: https://orcid.org/0000-0002-4595-6204

* corresponding author (e-mail: yahia.nasrallah@univ-saida.dz)

\begin{abstract}
The aim of this study was to establish an overview of medicinal plants in the Saida and El Bayadh regions through a survey of herbalists. Our survey included more than 60 herbalists spread over the territory of two Wilayas (provinces), in an area representing more than 3\% of Algerian territory. At the same time, and when conditions permitted, families were interviewed and their answers most often guided our survey. In addition, we collected information on: traditional herbalists, the most exploited species, areas of origin, periods and quantities exploited, as well as the influence of this mode of exploitation on present and future biodiversity in these regions. Analysis of the data showed that threats to the biological diversity of medicinal plants mainly included human actions and natural changes. Herbalists practise this trade mostly by inheritance and they are willing to train in the field of herbalism. The frequency of use of medicinal plants as alternative medicine is very important in the social life of populations.
\end{abstract}

Keywords: impact, exploitation, medicinal plants, biodiversity, conservation, Saida, El Bayadh

\section{Introduction}

Various plants have long been used by humans to treat different kinds of diseases. Today, mainly because the ineffectiveness of certain drugs, herbal treatments are back again in the foreground. There has been a revival towards a gradual interest in the use of medicinal plants in both developed and developing countries, because herbs can be used as a cure with fewer side effects (Fouché et al. 2008; Uprety et al. 2012). According to WHO reports (2003) and IUCN recommendations (2011), the use of traditional medicine has experienced renewed global attention and interest in recent decades. In fact, $40 \%$ of the Chinese population use plants for treatment, compared to $71 \%$ and $65 \%$, respectively in Chile and India. Traditional, complementary and alternative medicines are also of interest in developed countries. For example, the percentage of the population using such medicines is $48 \%$ in Australia, $70 \%$ in Canada, $49 \%$ in France and $42 \%$ in the United States of America. According to Gurib-Fakim (2006) and Ouarghidi et al. (2012) traditional medicine is the first means of care for more than $80 \%$ of people in developing countries because of its geographical, economic and cultural accessibility.

In order to support the implementation of sustainable natural resource management strategies, aware of all forms of biodiversity degradation, Agenda 21 insisted on the need to collect, at the local, regional and global level, more and more diverse data about the state and the evolution of ecosystem and natural resource variables (DRAFT 2008).

The region of western Algeria, like all other regions of Algeria, contains an important source of medicinal plants little known and poorly valued. While all stakeholders (especially scientists and environmentalists) 
agree on specific links between health and biodiversity, they are mostly concerned about the degradation of biodiversity and these consequences on the functioning of ecosystems (Hance 2011; Thompson et al. 2011; Phalan et al. 2018). This concern is amplified by selective and targeted collection of medicinal plants, from forest and steppe environments already threatened by all forms of anthropogenic pressures (delving, overgrazing, cutting and incineration of vegetation, pollution) (BiedCharreton 2007; Rajeswara Rao et al. 2012; Mackey \& Bryan 2012; WHO 2015).

There are few data concerning impacts of climate and anthropogenic phenomena of plant resource degradation on the vulnerability of medicinal plants according to geographical areas. Many questions remain unsolved such as: How and in which states these medicinal plants are given to consumers? What are the quantities exploited and the most requested species? The aim of this current study was to establish an overview of medicinal plants through a survey and among herbalists in the Wilayas of Saida and El Bayadh.

\section{Materials and methods}

\subsection{Studied areas}

The studied area covered the territories of the Wilayas (provinces) of Saida and El Bayadh, including, respectively, a large area between the Telian Atlas in the North and the northern Saharan Estrional in the south (Fig. 1).
Saida province is part of a geographical complex of the highlands and is naturally limited to the North by the Dhaya and Saida mountains and to the South by the Shott Ech-Chergui. It covers total area of $6765 \mathrm{~km}^{2}$ divided between 16 municipalities, with a population of 414980 inhabitants (General Population and Housing Census; GPHC 2008). This region is divided into three large natural areas according to the Ministry of Agriculture and Rural Development (MADR 2009):

- The agro-forest zone in the North is characterized by its climatic homogeneity and rainfall between 300 and $400 \mathrm{~mm}$ per year;

- The agro-pastoral zone is characterized by cereals on shallow soils and annual rainfall of no more than $300 \mathrm{~mm}$;

- The steppe is a pastoral zone par excellence, on poor and shallow soils and average annual rainfall ranging from 200 to $250 \mathrm{~mm}$.

The Wilaya of El Bayadh is geographically located between the 30-42' and 34-28' parallels of North latitude and the meridians of longitude 0-24' to the West, point 30 and 2-16' to the East. It occupies the area of $71,697 \mathrm{~km}^{2}$ ( $3 \%$ of the Algerian territory). It stretches from the Shott Ech-Chergui to the Western Erg and is dominated by the three mountains of Jebel Amour of the Saharan Atlas Range, the Boudergua (1873 meters of altitude), El Ouestani, with 1878 meters of altitude and the great Ksel with 2008 meters of altitude.

Structurally, the Wilaya of El Bayadh is listed in three different zones: (a) high plains to the North, which are the continuity of the steppe zone of Saida,

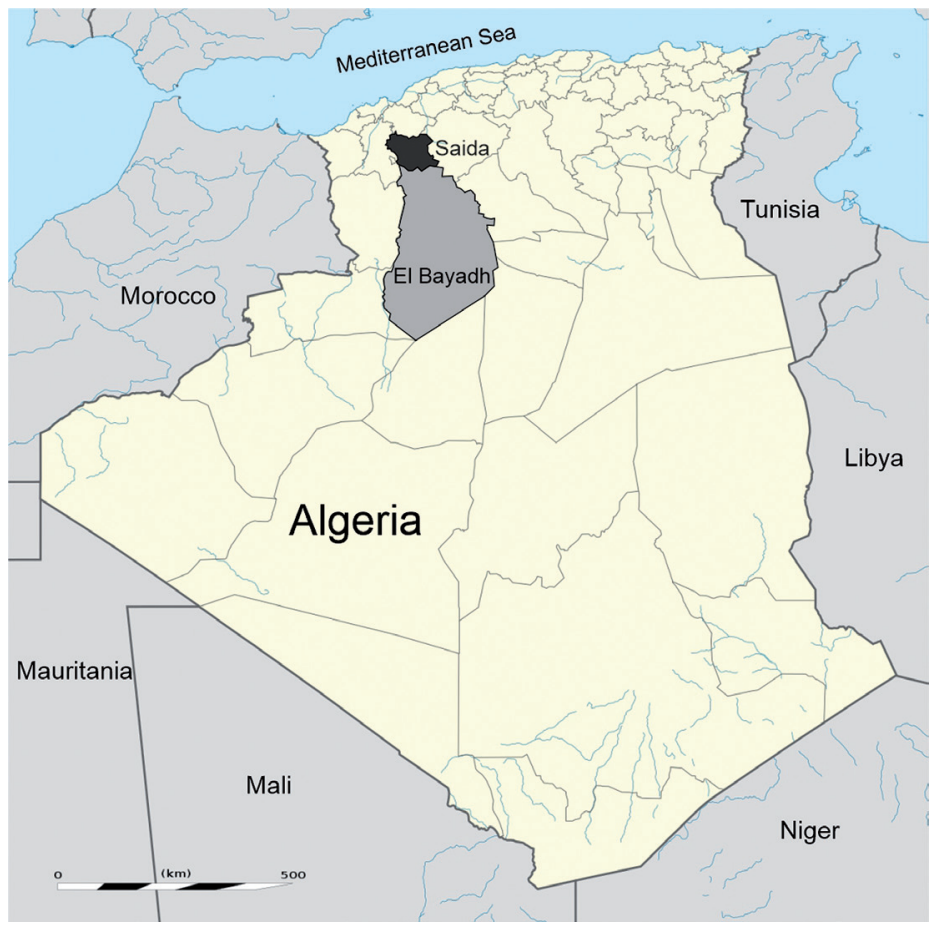

Fig. 1. Geographical location of studied regions (https://commons.wikimedia.org/wiki/File:Algeria_location_map.svg,) 
characterized by cool arid bioclimate, (b) the Saharan Atlas characterized by semi-cold-arid bioclimatic. Precipitation is relatively higher than other areas, winter is more severe and snow cover exceeds 10 days per year, (c) the pre-Saharan area representing the largest area of the Wilaya ( $71 \%$ of the total area). In this third zone, rainfall rarely exceeds $130 \mathrm{~mm} /$ year and agricultural activity is limited to the Ksour level according to the National Agency for Spatial Planning (NASP 2003).

\subsection{Methodology}

We went directly through field surveys to users (resellers and consumers) of medicinal plants. The questions asked during interviews were of two types: closed and semi-closed (Alfa 2011). Closed questions had the advantage of facilitating creation of statistical variables. Their disadvantage, however, was that herbalists did not disclose all the information, either for fear of being disclosed to authorities or by professional secrecy. The semi-closed questions had the advantage of recovering some of the aspects not mentioned when asked using closed questions.

At the same time, and when conditions permitted, families were interviewed and their responses were taken into consideration in our survey. The questionnaire was prepared in such a way that the answers were either Yes or No, or in the form of the modalities proposed by Alfa (2011), such as: never, rarely, sometimes, often, and always). In addition, our questions concerned the collection of information about traditional herbalists, the most exploited species, regions of origin, periods and quantities of plants sold, as well as the influence of this mode of exploitation on present and future of biodiversity in these regions. Statistical analyses of the data were carried out using Excel, SPSS and Sphinx software.
Subsequently and in order to evaluate the species most used and most requested by the population, the formula of Lance et al. (1994) was used to calculate the use index of each species, also expressed by the Relative Frequency of Citation (RFC) (Tardio \& PardoDe-Santayana 2008).

\subsection{Use Index}

\section{U. I. $(\%)=\mathrm{n} / \mathrm{N} \times 100$}

With n: number of people citing the species, $\mathrm{N}$ : total number of people surveyed. When this value (U.I.) was between 60 and $100 \%$, the species was widely known and widely used; If its value was between 30 and $60 \%$, the species was moderately known and moderately used; if(U.I) was less than $30 \%$, the species was little known and not too much used.

\section{Results}

Our results were based, primarily, on the interpretation of the statistical analysis of the survey of traditional herbalists and families. The statistically significant results were commented on. The list of medicinal plants initially covered 130 species, all unidentified species in herbalists and the families surveyed were eliminated.

\subsection{Socio-professional and cultural profile of herbalists}

- Experience of herbalists

Statistical analysis of the survey was significant for herbalists in El Bayadh $\left(\mathrm{Chi}_{2}=9,80, \mathrm{ddl}=2,1-\mathrm{p}=2.03 \%\right.$ ) and not significant for Saida herbalists $\left(\mathrm{Chi}_{2}=2.60\right.$, $\mathrm{ddl}=2,1-\mathrm{p}=72,75,0 \%)$. Experience did not affect the trade at the Wilaya of Saida, but it impacted the trade in El Bayadh $(83.3 \%$ of herbalists had less than 20 years of experience) (Fig. 2).

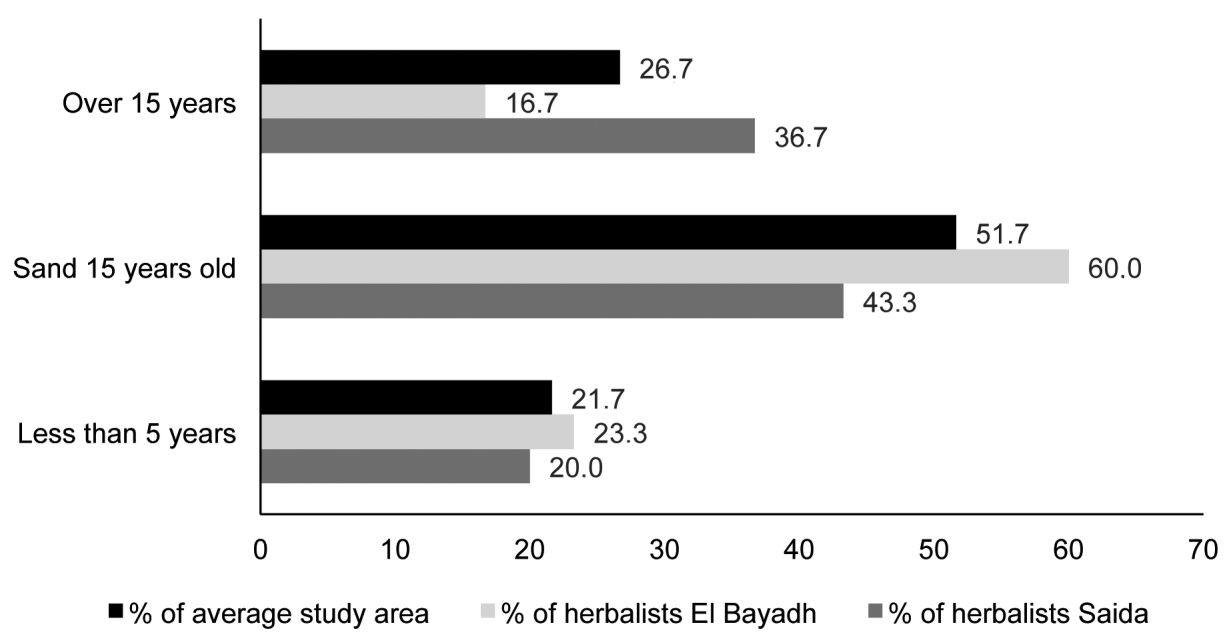

Fig. 2. Impact of experience on the herbalist trade in Saida and El Bayadh provinces, Algeria 


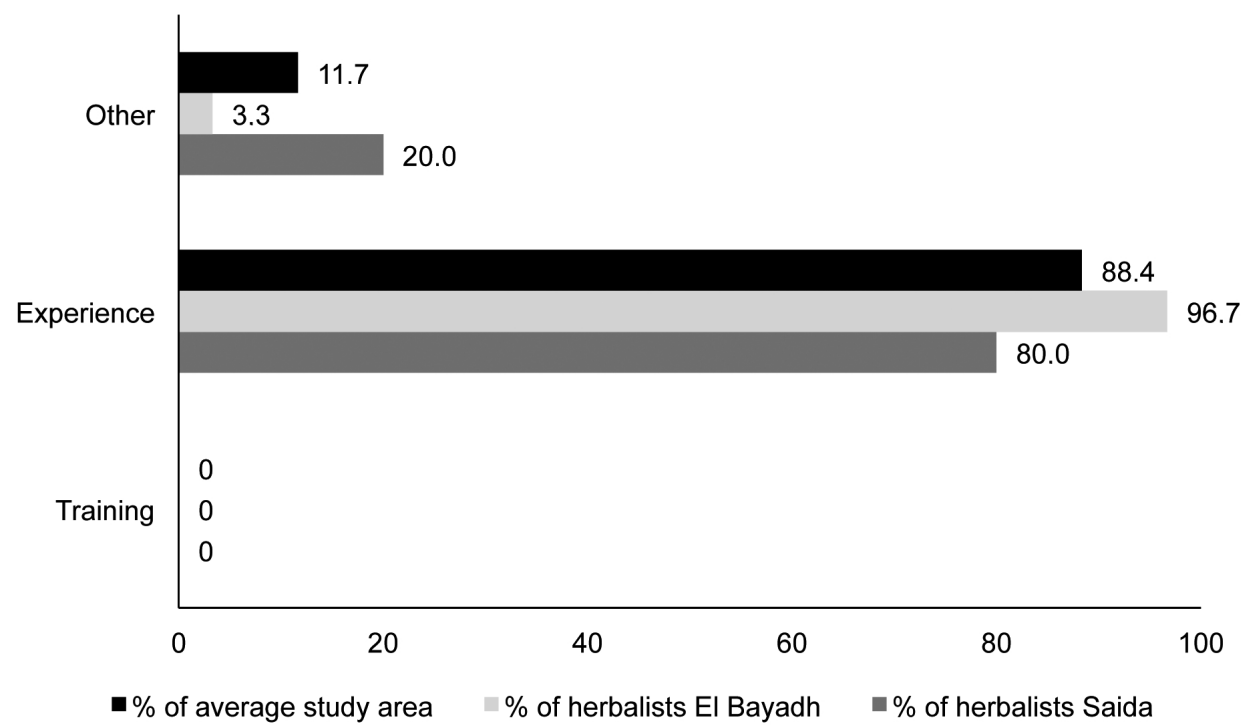

Fig. 3. Qualification of herbalists from Saida and El Bayadh, Algeria

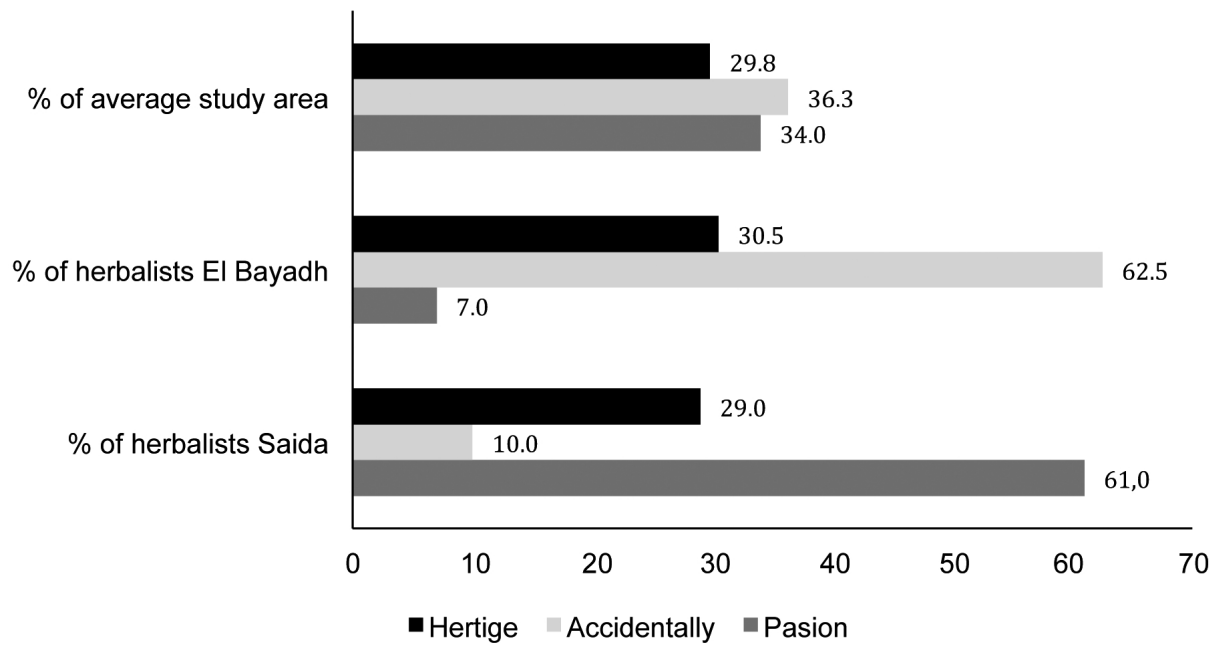

Fig. 4. Choice of herbalism in Saida and El Bayadh provinces, Algeria

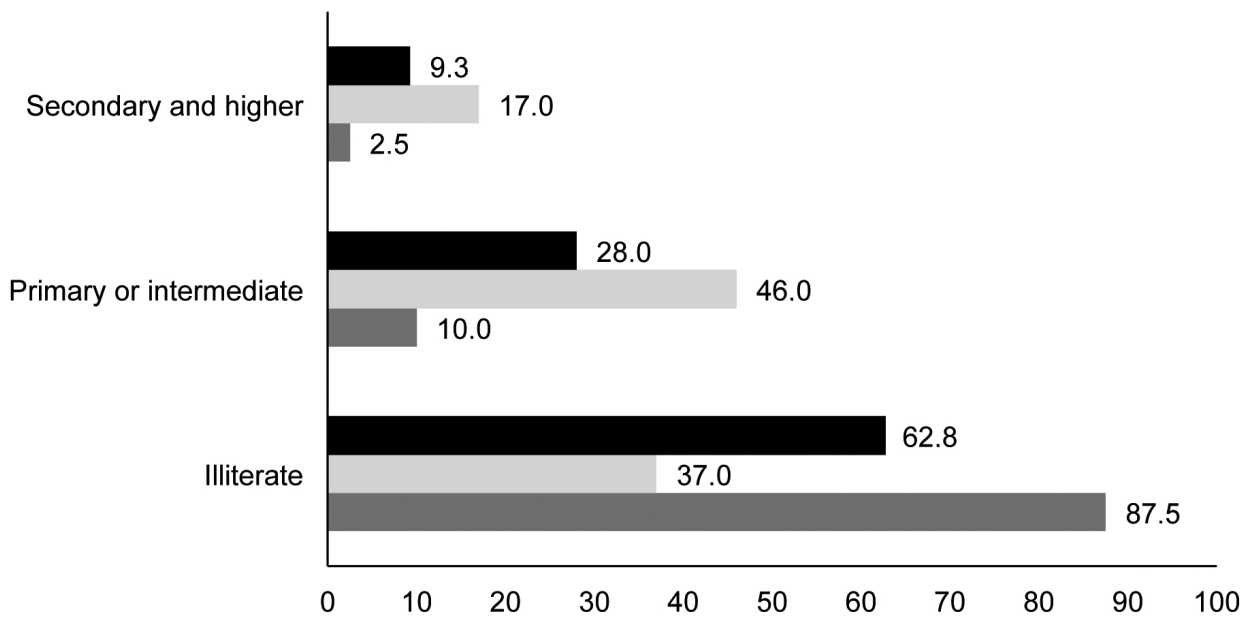

- \% of average study area $\quad \%$ of herbalists El Bayadh $\quad$ \% of herbalists Saida

Fig. 5. Education levels of herbalists in Saida and El Bayadh provinces, Algeria 
- Qualification of herbalists

Statistical analysis of the survey revealed a significant effect of qualification on the trade of herbalists from both regions. Eighty percent $(80 \%)$ of Saida herbalists said that they came to the profession through practice $\left(\mathrm{Chi}_{2}=24, \mathrm{ddl}=3.1,-\mathrm{p}=99,99 \%\right)$, compared to $96.70 \%$ for El Bayadh $\left(\mathrm{Chi}_{2}=26.13, \mathrm{ddl}=1,1-\mathrm{p}=0.01 \%\right)$. None of the 60 herbalists surveyed received training in the field (Fig. 3).

- Choice of trade

The distribution of responses to the trade choice variable was significant for Saida herbalists $\left(\mathrm{Chi}_{2}=26.13\right.$, $\mathrm{ddl}=1,1-\mathrm{p}=99.99 \%)$ and El Bayadh $\left(\mathrm{Chi}_{2}=8.60, \mathrm{ddl}=3\right.$, $1-p=3.51 \%$ ). Approximately $96,7 \%$ of herbalists came to the trade by pure patience at Saida. However, $62.5 \%$ did not choose this trade by themselves and 30.5\% inherited it at El Bayadh (Fig. 4).

- Level of education of herbalists

Statistical analysis of the survey was very significant $\left(\mathrm{Chi}_{2}=30, \mathrm{ddl}=1,1-\mathrm{p}=99.99\right)$ and $\left(\mathrm{Chi}_{2}=30.00, \mathrm{ddl}=1\right.$, $1-\mathrm{p}=0.01 \%$ ) in both Wilayas, respectively. The average illiteracy rate in the ranks of herbalists was $62.24 \%$. Only $9.25 \%$ of herbalists had secondary level education throughout the region (Fig. 5).

\subsection{Floristic and ethnobotanical aspect}

Floristic analysis of questionnaires identified 91 medicinal plants in the studied area (Saida, El Bayadh) divided into 43 families (Appendix 1). Families were represented as follows: Lamiaceae (14 species), Asteraceae (9), Apiaceae (7), Poaceae (6), Fabaceae (5), Amaranthaceae, Asphodelaceae, Cupressaceae with 3 species each; Anacardiaceae, Ericaceae, Lythraceae, Myrtaceae, Rosaceae, Urticaceae with 2 species each, and Apocynaceae, Boraginaceae, Brassicaceae, Cactaceae, Caryophyllaceae, Cucurbitaceae, Ephedraceae, Gentianaceae, Juglandaceae, Lauraceae, Liliaceae, Linaceae, Malvaceae, Nitrariaceae, Oleaceae, Plumbaginaceae, Ranunculaceae, Resedaceae, Rhamnaceae, Rubiaceae, Rutaceae, Salicaceae, Tamarixaceae, Thymelaeaceae, Verbenaceae, Vitaceae, Zingiberaceae with 1 species each.

- Medicinal plants available in herbalists

Analysis of the list of plant species most commonly found among herbalists showed that 22 species represented above $60 \%$ (Table 1), making up $23.1 \%$ of all species sold by Saida herbalists. At El Bayadh, this list of plant was represented by 21 species, with a marketing

Table 1. Species available from herbalists in Saida Wilaya

\begin{tabular}{|c|c|c|c|c|c|}
\hline Arabic name & Scientific name* & $\mathrm{n} / \mathrm{N}(\%)$ & Arabic name & Scientific name & $\mathrm{n} / \mathrm{N}(\%)$ \\
\hline عرق سوس & Glycyrrhiza glabra & 93.3 & بلوز & Asphodelus microcarpus & 80.0 \\
\hline 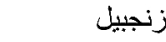 & Zingiber officinale & 90.0 & حبق & Vaccinium myrtillus & 80.0 \\
\hline عرعر & Tetraclinis articulata & 83.3 & 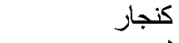 & Artemisia dracunculus & 76.7 \\
\hline 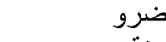 & Pistacia lentiscus & 83.3 & لوز & Prunus dulcis & 70.0 \\
\hline حنة & Lawsonia inermis & 83.3 & تسكرة & Echinops spinosus & 63.3 \\
\hline بيونج & Matricaria aurea & 83.3 & عين بقزة & Crataegus monogyna & 63.3 \\
\hline زعثر & Thymus vulgaris & 83.3 & زيتون & Olea europaea & 60.7 \\
\hline زريعة الكتان & Linumusita tissimum & 83.3 & دقلة & Nerium oleander & 60.7 \\
\hline 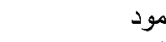 & Chamaerops humilis & 83.3 & خرطان & Avena sativa & 60.7 \\
\hline فوة إن & Galium mollugo & 83.3 & 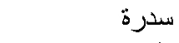 & Ziziphus lotus & 60.7 \\
\hline 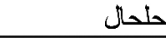 & Lavandula angustifolia & 80.0 & يازير & Rosmarinus officinalis & 60.7 \\
\hline
\end{tabular}

Explanations: * - according to The Plant List (2013), n - number of people citing the species, N-total number of people surveyed

Table 2. Species available from herbalists in El Bayadh Wilaya

\begin{tabular}{|c|c|c|c|c|c|}
\hline Arabic name & Scientific name & $\mathrm{n} / \mathrm{N}(\%)$ & Arabic name & Scientific name & $\mathrm{n} / \mathrm{N}(\%)$ \\
\hline عريش & Tamarix gallica & 100.0 & فوبجل & Ruta chalepensis & 83.3 \\
\hline قرطوفه & Anacyclus valentinus & 100.0 & قطف & Atriplex hallimus & 83.3 \\
\hline شيح & Artemisia herba-alba & 90.0 & رمث & Hammada scoparia & 83.3 \\
\hline فتات الحجر & Parietaria officinalis & 90.0 & ش تشندقورن & Ajuga iva & 70.0 \\
\hline 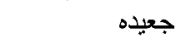 & Teucrium polium & 90.0 & قندول & Calicotome spinosa & 66.7 \\
\hline 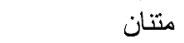 & Thymelaea hirsuta & 90.0 & 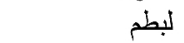 & Pistacia atlantica & 66.7 \\
\hline نجم & Cynodon dactylon & 90.0 & 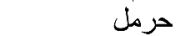 & Peganum harmala & 66.7 \\
\hline زنجييل & Zingiber officinale & 88.3 & رتم & Retama raetam & 66.7 \\
\hline حنه & Lawsonia inermis & 83.3 & حلبه & Trigonella foenum-graecum & 63.3 \\
\hline إكليل & Rosmarinus officinalis & 83.3 & 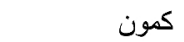 & Cuminum cyminum & 63.3 \\
\hline زيتر & Thymus algeriensis & 83.3 & & & \\
\hline
\end{tabular}

Explanations: $\mathrm{n}$ - number of people citing the species, $\mathrm{N}$ - total number of people surveyed 
Table 3. Moderately available species among herbalists in Saida Wilaya

\begin{tabular}{|c|c|c|c|c|c|}
\hline Arabic name & Scientific name & $\mathrm{n} / \mathrm{N}(\%)$ & Arabic name & Scientific name & $\mathrm{n} / \mathrm{N}(\%)$ \\
\hline حريق & Urtica pilulifera & 56.8 & ق ق قرنفل & Syzygium aromaticum & 43.3 \\
\hline سانوج & Nigella sativa & 50.0 & مسو الك & Juglans regia & 40.0 \\
\hline لسان الثور & Borago officinalis & 50.0 & مرارة حنش & Centaurium erythraea & 40.0 \\
\hline مريوية & Marrubium vulgaris & 46.8 & ذرة & Zea mays & 33.3 \\
\hline حلبة & Trigonella foenum-graecum & 46.8 & حبق - حيق & Melissa officinalis & 33.3 \\
\hline 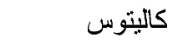 & Eucalyptus globulus & 46.8 & 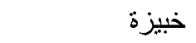 & Malva sylvestris & 33.3 \\
\hline طاقا & Juniperus communis & 46.8 & كرموس العرب & Ficus carica & 33.3 \\
\hline سالمية & Salvia officinalis & 46.8 & كرموس النصارى & Opuntia ficus-indica & 33.3 \\
\hline لويزة & Verbena officinalis & 46.8 & 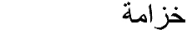 & Lavandula latifolia & 33.3 \\
\hline 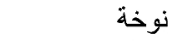 & Ammi visnaga & 43.3 & داليا & Vitis vinifera & 33.3 \\
\hline 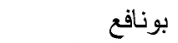 & Thapsia garganica & 43.3 & 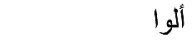 & Aloe vera & 33.3 \\
\hline شواك جمل & Silybum marianum & 43.3 & ثُوم & Allium sativum & 33.3 \\
\hline 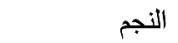 & Elymus repens & 43.3 & لنج & Arbutus unedo & 33.3 \\
\hline كمون & Cuminum cyminum & 43.3 & زرودية الخلا & Daucus carota & 33.3 \\
\hline
\end{tabular}

Explanations: $\mathrm{n}$ - number of people citing the species, $\mathrm{N}$ - total number of people surveyed

Table 4. Moderately available species among herbalists in El Bayadh Wilaya

\begin{tabular}{|c|c|c|c|c|c|}
\hline Arabic name & Scientific name & $\mathrm{n} / \mathrm{N}(\%)$ & Arabic name & Scientific name & $\mathrm{n} / \mathrm{N}(\%)$ \\
\hline سنوج & Nigella sativa & 56.7 & ق ق قزنفل & Syzygium aromaticum & 43.3 \\
\hline زبوج & Olea europaea & 56.7 & كرموس عرب & Ficus carica & 43.3 \\
\hline شهيبه & Artemisia absinthium & 56.7 & درين & Aristida pungens & 36.7 \\
\hline رند & Laurus nobilis & 56.7 & مودريقه & Ammodaucus leucotrichus & 36.7 \\
\hline رمان & Punica granatum & 56.7 & ز زيثزه & Thymus vulgaris & 33.3 \\
\hline 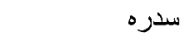 & Ziziphus lotus & 50.0 & زريعة كتان & Linumusita tissimum & 33.3 \\
\hline مخينزه - | مخي & Dysphania ambrosioides & 50.0 & لويزه & Verbena officinalis & 33.3 \\
\hline ت ت تاسلغه & Globularia alypum & 50.0 & ذرا & Zea mays & 33.3 \\
\hline 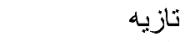 & Asphodelus refractus & 50.0 & ملفة الخادم & Limoniastrum feei & 33.3 \\
\hline 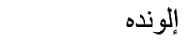 & Ephedra alata & 50.0 & 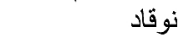 & Asteriscus pygmaeus & 33.3 \\
\hline عرعار صحراء & Juniperus phoenicea & 50.0 & حلفه & Stipa tenacissima & 33.3 \\
\hline حلحل & Lavandula angustifolia & 43.3 & خباطه & Phlomis bovei & 33.3 \\
\hline عرق سوس & Glycyrrhiza glabra & 43.3 & فاسوخ & Ferula communis & 33.3 \\
\hline نوخه & Ammi visnaga & 43.3 & دفله & Nerium oleander & 33.3 \\
\hline
\end{tabular}

Explanations: $\mathrm{n}$ - number of people citing the species, $\mathrm{N}$ - total number of people surveyed

rate of 22.1\% (Table 2), three species: Zingiber officinale, Lawsonia inermis and Trigonella foenum-graecum were commonly present in both studied areas, but only Rosmarinus officinalis was part of the local vegetation and sold in these regions.
- Moderately availability species in herbalists in both studied areas

The review of plant species presence (with presence rate between 30 and $60 \%$ ) among herbalists in the region was 28 species each at Saida and El Bayadh. However,

Table 5. Species poorly available $(<30 \%)$ from herbalists in Saida Wilaya

\begin{tabular}{|c|c|c|c|c|c|}
\hline Arabic name & Scientific name & $\mathrm{n} / \mathrm{N}(\%)$ & Arabic name & Scientific name & $\mathrm{n} / \mathrm{N}(\%)$ \\
\hline خزوب | خ خ خ & Ceratonia siliqua & 26.7 & ز زعيرة & Thymus algeriensis & 10.0 \\
\hline كعالة خروف & Reseda alba & 26.7 & فيجل & Ruta chalepensis & 10.0 \\
\hline صفصاف الماء & Salix alba & 26.7 & قطف & Atriplex hallimus & 10.0 \\
\hline 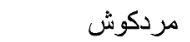 & Origan marjolaine & 26.7 & ل & Hammada scoparia & 10.0 \\
\hline نعناع & Mentha arvensis & 26.7 & شُندقورة & Ajuga iva & 10.0 \\
\hline معدنوس & Sinapis arvensis & 26.7 & بطم & Calicotome spinosa & 6.7 \\
\hline معدنوس & Petroselinum crispum & 26.7 & بطم & Pistacia atlantica & 6.7 \\
\hline عريش & Tamarix gallica & 26.7 & حرمل & Peganum harmala & 6.7 \\
\hline فتاتة حجر & Parietaria officinalis & 26.7 & رثم & Retama raetam & 6.7 \\
\hline قرطوفة & Anacyclus valentinus & 26.7 & زبوج & Olea europaea & 6.7 \\
\hline جعيدة & Teucrium polium & 10.0 & مخينزة & Dysphania ambrosioides & 6.0 \\
\hline مثنان & Thymele ahirsuta & 10.0 & تسلغة & Globularia alypum & 6.0 \\
\hline نجم & Cynodon dactylon & 10.0 & تازية & Asphodelus refractus & 3.3 \\
\hline
\end{tabular}

Explanations: $\mathrm{n}$ - number of people citing the species, $\mathrm{N}-$ total number of people surveyed 
Table 6. Species poorly available $(<30 \%)$ from herbalists in El Bayadh Wilaya

\begin{tabular}{|c|c|c|c|c|c|}
\hline Arabic name & Scientific name & $\mathrm{n} / \mathrm{N}(\%)$ & Arabic name & Scientific name & $\mathrm{n} / \mathrm{N}(\%)$ \\
\hline كلثوس & Eucalyptus globulus & 26.7 & حدج & Citrullus colocynthis & 26.7 \\
\hline بونافع & Thapsia garganica & 26.7 & نابطَه & Clinopodium nepeta & 26.7 \\
\hline النجم & Elymus repens & 26.7 & فوّوه & Galium mollugo & 10.0 \\
\hline مسو آك & Juglans regia & 26.7 & ت ت ت اسكره & Echinops spinosus & 10.0 \\
\hline مرارة حنش & Centaurium erythraea & 26.7 & 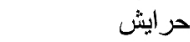 & Borago officinalis & 10.0 \\
\hline كرموس نصاره & Opuntia ficus-indica & 26.7 & جفنه & Gymnocarpos decander & 6.0 \\
\hline
\end{tabular}

Explanations: $\mathrm{n}$ - number of people citing the species, $\mathrm{N}$ - total number of people surveyed

only 4 species: Zea mays, Ammi visnaga, Verbena officinalis, Nigella sativa were common and marketed in both studied areas (Tables 3-4).

- Species not available in herbalists in both studied areas

The study of the list of medicinal plants whose presence was less than 30\% showed that 26 species $(27.4 \%)$ at Saida and 12 species (12.6\%) at El Bayadh were not widely available among herbalists in these two provinces (Tables 5-6).
- Species absent in herbalists

15 species (15.8\%) absent among Saida herbalists were available, but at different levels at El Bayadh herbalists (Tables 7-8). Among the herbalists of El Bayadh, 30 species, either $30.5 \%$ of all the species recorded were absent, but also present at different levels in the Wilaya of Saida. According to herbalists, these plants were absent, either because they were not in demand and were not part of the region's traditions, or because they were not available, although they were requested by users.

Table 7. Species absent from herbalists in Saida

\begin{tabular}{|c|c|c|c|}
\hline Arabic name & Scientific name & Arabic name & Scientific name \\
\hline 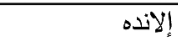 & Ephedra alata & شُهيبه & Artemisia absinthium \\
\hline عزعار صحر اء & Juniperus phoenicea & خياطه & Phlomis bovei \\
\hline درين & Aristida pungens & نابطة & Clinopodium nepeta \\
\hline ملفت خادم & Limoniastrum feei & رند & Laurus nobilis \\
\hline 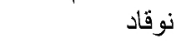 & Asteriscus pygmaeus & رمان & Punica granatum \\
\hline جفنه & Gymnocarpos decander & فاسوخ & Ferula communis \\
\hline حلفه & $\begin{array}{l}\text { Citrullus colocynthis } \\
\text { Stipa tenacissima }\end{array}$ & مودريقة & Ammodaucus leucotrichus \\
\hline
\end{tabular}

Table 8. Species absent from herbalists in El Bayadh

\begin{tabular}{|c|c|c|c|}
\hline Arabic name & Scientific name & Arabic name & Scientific name \\
\hline عرعار & Tetraclinis articulata & مليلسه & Melissa officinalis \\
\hline ضرو & Pistacia lentiscus & خبيزه & Malva sylvestris \\
\hline بلوز & Asphodelus microcarpus & خزامه & Lavandula latifolia \\
\hline بابونج & Matricaria aurea & دالبه & Vitis vinifera \\
\hline دوم & Chamaerops humilis & ألوه & Aloe vera \\
\hline حبق & Vaccinium myrtillus & لنج & Arbutus unedo \\
\hline قنجز & Artemisia dracunculus & زروبيت خلا & Daucus carota \\
\hline لوز & Prunus dulcis & خروب & Ceratonia siliqua \\
\hline عين بقره & Crataegus monogyna & كعالت خروف & Reseda alba \\
\hline زيثون & Olea europaea & صفصاف ماء & Salix alba \\
\hline خزطان & Avena sativa & مريقوش & Origanum majorana \\
\hline حريق & Urtica pilulifera & خردل & Sinapis arvensis \\
\hline لمسان ثور & Borago officinalis & معنوس & Petroselinum crispum \\
\hline مرويه & Marrubium vulgaris & شوك جمل & Silybum marianum \\
\hline طاقه & Juniperus communis & سلمبيه & Salvia officinalis \\
\hline
\end{tabular}




\section{Discussion}

Our survey covered all 38 municipalities in the two provinces and, therefore, concerned the entire population and the diversity of environments and vegetation, from the Tellian Atlas in the North to the Northern part of the Sahara in the South of the Saharan Atlas.

Analysis of the survey data showed that in both studied areas, the profession of herbalist was most often practiced, either by inheritance or coincidence. In fact, even if the majority of herbalists were able to name the plant, giving its origin and providing its medical use, this information remained imprecise or insufficient for species identification purposes (Kool et al. 2012). The majority of herbalists had less than 20 years of experience, which reinforced the idea of rediscovering the population of the virtues of medicinal plants (GuribFakim 2006; Ouarghidi et al. 2013; WHO 2015). These discoveries were facilitated by the availability of multiple studies on plants and the many side-effects, if not the failure of chemical-based drugs in the treatment of certain diseases. Vast majority $(83.3 \%)$ of herbalists in both regions were illiterate and not all received any training to practise this profession. Relatively, similar results were recorded in Morocco (Benkhnigue et al. 2011; Kool et al. 2012; Ouarghidi et al. 2012, 2013; Teixidor-Toneu et al. 2016), in Tunisia by Jdaidi and Hasnaoui (2016), in South-Western Burkina Faso by Traoré et al. (2011) and Niger by Hama et al. (2019).

Our investigations showed that of 130 medicinal plants mentioned by the families consulted, 95 were present among herbalists. Similar results were reported by Tahri et al. (2012) in Settat province in Morocco. The rest of the species were used directly by families, either because of their availability among herbalists or because of their specific medical use. Medicinal plants were, in most cases, collected from the forest and steppes, mostly to avoid harvesting plants treated with fertilizers and pesticides. However, in Algeria, these environments are open to public (a collective property), which everyone derives the maximum benefit without compensation. Many plants have become difficult to find because of destruction of their habitat.

Floral analysis showed that 91 medicinal plants inventoried by herbalists in Saida and El Bayadh are divided into 43 families. The most represented families were: Lamiaceae, Asteraceae, Apiaceae, Poaceae and Fabaceae. These results confirmed those obtained in two different regions of Morocco: the high Moulouya (Benlamdini et al. 2014) and the high Atlas (TeixidorToneu et al. 2016), respectively.

The study of the Ethnobotanical Use Value (Use Index or U.V) showed that exploited species did not have the same socio-economic value for populations. Consequently, they did not face identical anthropogenic pressures. Those with high UVs were most exploited. The threat level of any plant species was directly related to its use by the local population; the more it was used, the higher risk of disappearance it experienced. In our study, the utilization index permitted to classify $23.1 \%$ and $22.1 \%$ of the traded species, respectively in Saida in El Bayadh, in the upper threshold of $60 \%$; which could be considered as available species (Rakotoarivelo et al. 2015). The species with an average rate of presence between 30 and $60 \%$ were more frequently used $(29.5 \%)$ among herbalists in the two provinces. A review of the list of species present in each province showed that few species were common to both provinces, such as: Zea mays, Ammi visnaga, Verbena officinalis and $\mathrm{Ni}$ gella sativa. Floral analysis of medicinal plants among herbalists showed that $15.8 \%$ of species in Saida and $30.5 \%$ in El Bayadh were absent. Our data correspond to those reported by (Koudouvo et al. 2017) in Ivory Coast. The low use of these species by the population may be due to many reasons. However, performed surveys and inventories support the hypothesis of their progressive extinction from these areas (Dossou et al. 2012; Benlamdini et al. 2014).

All species with a frequency of use less than $20 \%$ were considered rare (Kokou 2001; Koudouvo et al. 2017). The comparison of our data with floristic inventories (Quezel \& Santa 1962) made it possible to distinguish certain rare species common to both studied areas, such as: Teucrium polium (protected), Thymelaea hirsuta, Cynodon dactylon, Thymus algeriensis, Ruta chalepensis, Atriplex hallimus, Hammada scoparia, Ajuga iva, Aristida purgens, Clinopodium nepeta, Asteriscus pygmaeus, Gymnocarpos decander and Peganum harmala. Other rare species such as: Ruta chalepensis, Calicotome spinosa, Retama raetam, Laurus nobilis, Dysphania ambrosioides, Globularia alypum, Phlomis bovei and Ferula communis were specific to the first zone. The third category concerned the rare species specific to the second zone and included: Asphodelus refractus, Juniperus phoenicea, Citrullus colocynthis and Ammodaucus leucotrichus. Other rare species in both studied areas were available on the market, without going through herbalists, as was the case with: Stipa tenacissima, Artemisia absinthium and Punica granatum.

\section{Conclusion}

This study covered a large area located from the Tellian Atlas in the North to northern part of Algeria in South Sahara of the Saharan Atlas, representing a total area of $3.2 \%$ of Algerian territory. The objective was to draw up an inventory of area little documented by scientific research, namely the impact of traditional methods of exploitation and enhancement of medicinal plants on biodiversity. 
Calculation of the medicinal plant utilization index (MPUI) indicated that $23.1 \%$ and $22.1 \%$ of the species used by the population at Saida and El Bayadh, respectively were considered available species. In fact, $29.5 \%$ of the species present among herbalists in each of the two provinces were classified as moderately available category, and $15.8 \%$ and $31.6 \%$ of the species used in Saida and El Bayadh, respectively were poorly available among herbalists. According to Dossou et al. (2012), the value of ethnobotanical use helps to identify very useful species under high pressure. These species should be considered as priorities in the management of natural environment, in order to contribute to economic and socio-cultural development of populations.

Our investigations with herbalists in this large region showed that current organization of the exploitation and use of medicinal plants was deficient on several levels:

The profession of herbalist should be more organized as other official medical professions, since there was potential risk for human health in case of misidentification or incorrect-prescription of herbs. In addition, rare and endangered species could be collected inadvertently by confusion with their relatives (Kool et al. 2012). In West European and North American societies (Canada and United States) (Bicton et al. 2016), this profession is practised by educated and qualified persons in the field of herbal medicine, whereas in African countries such as Algeria, the profession of herbalist is practised by illiterate people who lack certain rules of harvesting and conservation of plants. It is, therefore, time to think about offering them an adapted training in order to complete and secure this important practice. To start off, it is necessary to offer an adapted basic training to the herbalists already in place, to complete, orient and to secure this important profession in relation to human health. The next step would be to make the population and, above all, the health authorities aware of the importance of the herbalist profession. Especially, they should be made aware of potential risks to human health and life if this profession continues to be exercised by unqualified people. The aim is to protect the profession of herbalists from any abuse by regular laws and, especially, to introduce this alternative medicine speciality into education programs of colleges and universities in order to form future qualified herbalists.

Plant exploitation is often carried out in an anarchic way, without knowledge of the quantitative and qualitative potential of plant species. So, in-depth studies on the biology and ecology of the species and the inventory of medicinal plants with locations of habitats and harvesting sites should be carried out. In addition, it seems necessary to quantify biomass and annual possibilities.

Identification of rare species and those in high demand is necessary to predict their production in nurseries.

\section{Author Contributions}

Research concept and design: Y. Nasrallah

Acquisition and/or assembly of data: Y. Nasrallah, S. A. Aouadj

Data analysis and interpretation: Y. Nasrallah, S. A. Aouadj

Drafting the article: S. A. Aouadj

Critical revision: H. Khatir

Final approval: H. Khatir, Y. Nasrallah

\section{References}

Alfa D. A. 2011. Valorisation de la médecine traditionnelle en contexte africain : expérience de "la maison de la feuille" à Porto Novo au Bénin. Mémo. Université d'Abomey-Calavi (Bénin), 84 pp.

Benkhnigue O., Zidane L., Fadli M., Elyacoub H., Rochdi A. \& Douira A. 2011. Etude ethnobotanique des plantes médicinales dans la région de Mechraâ Bel Ksiri (Région du Gharb du Maroc). Acta Botanica, Barcelona 53: 191-216.

Benlamdini N., Elhafian M., Rochdi A. \& Zidane L. 2014. Étude floristique et ethnobotanique de la flore médicinale du Haut Atlas oriental (Haute Moulouya). Journal of Applied Biosciences 78: 6771-6787.

Bicton C., Evans S. \& Avila C. 2016. The re-emergence of grassroots herbalism: an analysis through the blogosphere. Health Sociology Review 21(1): 108-121. DOI: $10.1080 / 14461242.2015 .1086956$

Bied-Charreton M. 2008. Integrating the combat against desertification and land degradation into negotiations on climate change: a winning strategy, UNCCD. http:// www.unccd.int/science/docs/non_paper_desertif_Climate_eng. pdf.

Dossou M. E., Houessou G. L., Lougbégnon O. T., Tenté A. H. B. \& CodjiA J. T. C. 2012. Étude ethnobotanique des ressources forestières ligneuses de la forêt marécageuse d'Agonvè et terroirs connexes au Bénin. Tropicultura 30(1): 41-48.

DRAFT. 2008. Surveiillance environnementale à long terme en réseau ciircum-sahariien: synthèse Afrique du nord "Flore - végétation - occupation des terres". http:// www.oss-online.org/cd_envi/doc-new/02/07/02/02.pdf

Fouché G., Cragg G. M., Pillay P., Kolesnikova N., Maharaj V. J. \& Senabe J. 2008. In vitro anticancer screening of South African plants. Journal of Ethnopharmacology 119(3): 455-461.

GuRIB-FAKIM A. 2006. Medicinal plants: Traditions of yesterday and drugs of tomorrow. Molecular Aspects of Medicine 27(1): 1-93. 
Hama O., Kamou H., Ali Abdou M. M. \& Saley K. 2019. Connaissances ethnobotaniques et usages de Combretummicranthum dans la pharmacopée traditionnelle au Sud-ouest de Tahoua (Niger, Afrique de l'Ouest). International Journal of Biological and Chemical Sciences 13(4): 2173-2191.

HANCE J. 2011. Cambodian prime minister cancels titanium mine project citing impact on biodiversity and local people. http://news.mongabay.com/2011/04/cambodian-prime-minister-cancels-titanium-mine-projectciting-impact-on-biodiversity-and-local-people

IUCN 2011. IUCN Species Survival Commission Medicinal Plant Specialist Group. Why conserve and manage medicinal plants Accessed November 17. http://www. iucn.org/themes/ssc/sgs/mpsg/main/Why.html

Jdaidi N. \& Hasnaoui B. 2016. Étude floristique et ethnobotanique des plantes médicinales au Nord-ouest de la Tunisie: cas de la Communauté d'Ouled Sedra. Journal of Advanced Research in Science and Techno$\operatorname{logy} 3(1): 281-291$.

Koкоu K. 2001. Biodiversité médicinale au sud du Togo. Journal de la Recherche Scientifique de l'Université de Lomé. Univ. Bénin (Togo) 5(1): 117-124.

Kool A., De Boer H. J., Krüger Å., Rydberg A., Abbad A., BJÖRK L. \& MARTIN G. 2012. Molecular identification of commercialized medicinal plants in Southern Morocco. PLoS ONE 7(6): 1-12.

Koudouvo K., Denou A., Esseh K., Sanogo R., Essien K., Diallo D., Kokou K., Tozo S. K., Aklikokou K., Aguiyi J. C. \& GbéAssor M. 2017. Ethnobotanical Survey of Endangered Antimalarial and Analgesic Plants of Togo for the Safeguard of the Medicinal Biodiversity. Journal of Agriculture and Ecology Research International 12(2): 1-9.

LANCE K., KRemen C.\& Raymond I. 1994. Extraction of forest Products: quantitative of park and buffer zone and long-term monitoring. Report to Park Delimitation Unit, WCS/PCDIM, Antananarivo, pp 549-563.

MACKeY T. K. \& BRYAN A. L. 2012. Integrating Biodiversity Management and Indigenous Biopiracy Protection to Promote Environmental Justice and Global Health. Am J Public Health 102(6): 1091-1095. doi: 10.2105/ AJPH.2011.300408

Ministère de L'Agriculture et du Développement RuRAL (MARD). 2009. Statistiques Agricoles Série B Année, Alger, 64 pp.

NASP 2003. National Agency for Spatial Planning. Prospective development study of the wilaya of El Bayadh. $35 \mathrm{pp}$.

Ouarghidi A., Powell B., Martin G. J., De Boer H. \& Abbad A. 2012. Species substitution in medicinal roots and possible implications for toxicity of herbal remedies in Morocco. Econ Bot 66(4): 370-382.

Ouarghidi A., Martin G. J., Powell B., Esser G. \& Abbad A. 2013. Botanical identification of medicinal roots collected and traded in Morocco and comparison to the existing literature. Journal of ethnobiology and ethnomedicine 9(59): 1-13.
Phalan B., Hayes G., Brooks S., Marsh D., Howard P., Costelloe B., Vira B., Kowalska A. \& Whitaker S. 2018. Avoiding impacts on biodiversity through strengthening the first stage of the mitigation hierarchy. Cambridge University Press 52(2): 316-324.

Quezel P. \& Santa S. 1962. Nouvelle Flore d'Algérie et des Régions Désertiques Méridionales. 2 Tomes, Editions CNRS, Paris, 1170.

Rajeshara Rao B. R., Syamasundra K. V., Rajput D. K., Nagaru G. \& Adinarayana G. 2012. Biodiversity, conservation and cultivation of medical plants. Journal of Pharmacognosy 3(2): 59-62.

Rakotoarivelo N. H., Rakotoarivony F., Ramarosandratana A. V., Jeannoda V. H., Kuhlman A. R., Randrianasolo A. \& Bussmann R. W. 2015. Medicinal plants used to treat the most frequent diseases encountered in Ambalabe rural community, Eastern Madagascar. Journal of Ethnobiology and Ethnomedicine 11: 68. https://doi.org/10.1186/s13002-015-0050-2

Tahri N., El Basti A., Zidane L., \& Douira A. 2012. Étude Ethnobotanique des Plantes Médicinales dans la Province de Settat (Maroc). Kastamonu Univ. Journal of Forestry Faculty 12(2): 192-208.

TARdio J. \& PARdo-De-SAntAYANA M. 2008. Cultural Importance Indices: A Comparative Analysis Based on the Useful Wild Plants of Southern Cantabria. Econ Bot 62(1): 24-39.

Teixidor-Toneu I., Martin G. J., Ouhammou A., Puri R. K. \& Hawkins J. A. 2016. An ethnomedicinal survey of a Tashelhit-speaking community in the High Atlas, Morocco. J Ethnopharmacol 188: 96-110.

The Plant List 2013. The Plant List. Version 1.1. Published on the Internet; http://www.theplantlist.org/ (accessed 30.12.2020).

Thompson I. D., Okabe K., Tylianakis J. M., Kumar P., Brockerhoff E. G., Schellhorn N. A., Parrotta J. A. \& NASI R. 2011. Forest Biodiversity and the Delivery of Ecosystem Goods and Services: Translating Science into Policy. Bioscience 61(12): 972-981. https://doi. org/10.1525/bio.2011.61.12.7

Traore M. 2010. Le Recours à la Pharmacopée Traditionnelle Africaine dans le nouveau millénaire: "Cas des Femmes Herboristes de Bamako". Centre d'Etudes et d'Actions pour l'Auto Développement, 15 pp.

Uprety Y., Asselin H., Dhakal A. \& Julien N. 2012. Traditional use of medicinal plants in the boreal forest of Canada: review and perspectives. J Ethnobiol Ethnomed 8(7): 1-14.

WHO 2003. National policy on traditional medicine and regulation of herbal medicines. Report of WHO global survey. Geneva: World Health Organization.

WHO 2015. Connecting global priorities: Biodiversity and human health: a state of knowledge review. WHO Library Cataloguing-in-Publication Data, pp. 63-74. 
Appendix 1. The list of medicinal plant species identified in the sociological survey and among herbalists in the Wilayas of Saida and El Bayadh

\begin{tabular}{|c|c|c|c|c|c|c|c|c|c|}
\hline \multirow{2}{*}{ Species name and synonim* } & \multirow{2}{*}{ Family name } & \multicolumn{8}{|c|}{ Table number } \\
\hline & & 1 & 2 & 3 & 4 & 5 & 6 & 7 & 8 \\
\hline Ajuga iva (L.) Schreb. & Lamiaceae & & $\bullet$ & & & $\bullet$ & & & \\
\hline Allium sativum $\mathrm{L}$. & Liliaceae & & & $\bullet$ & & & & & \\
\hline Aloe vera (L.) Burm. f. & Asphodelaceae & & & $\bullet$ & & & & & $\bullet$ \\
\hline Ammi visnaga (L.) Lam. & Apiaceae & & & $\bullet$ & • & & & & \\
\hline Ammodaucus leucotrichus (Coss. \& Dur.) Coss. \& Dur. & Apiaceae & & & & - & & & $\bullet$ & \\
\hline Anacyclus valentinus $\mathrm{L}$. & Asteraceae & & $\bullet$ & & & $\bullet$ & & & \\
\hline Arbutus unedo L. & Ericaceae & & & $\bullet$ & & & & & $\bullet$ \\
\hline Aristida pungens Desf. & Poaceae & & & & $\bullet$ & & & $\bullet$ & \\
\hline Artemisia absinthium L. & Asteraceae & & & & • & & & $\bullet$ & \\
\hline Artemisia dracunculus L. & Asteraceae & $\bullet$ & & & & & & & $\bullet$ \\
\hline Artemisia herba-alba Asso & Asteraceae & & $\bullet$ & & & & & & \\
\hline Asphodelus microcarpus Sarl. & Asphodelaceae & $\bullet$ & & & & & & & $\bullet$ \\
\hline Asphodelus refractus Boiss. & Asphodelaceae & & & & - & $\bullet$ & & & \\
\hline Asteriscus pygmaeus (DC.) Coss. \& Dur. & Asteraceae & & & & $\bullet$ & & & $\bullet$ & \\
\hline Atriplex hallimus L. & Amaranthaceae & & $\bullet$ & & & $\bullet$ & & & \\
\hline Avena sativa $\mathrm{L}$. & Poaceae & $\bullet$ & & & & & & & $\bullet$ \\
\hline Borago officinalis L. & Boraginaceae & & & $\bullet$ & & & • & & $\bullet$ \\
\hline Calicotome spinosa (L.) Link & Fabaceae & & $\bullet$ & & & $\bullet$ & & & \\
\hline Centaurium erythraea Rafn (Erythraea centaurium (L.) Pers.) & Gentianaceae & & & $\bullet$ & & & • & & \\
\hline Ceratonia siliqua $\mathrm{L}$. & Fabaceae & & & & & $\bullet$ & & & $\bullet$ \\
\hline Chamaerops humilis L. & Arecaceae & - & & & & & & & $\bullet$ \\
\hline Citrullus colocynthis (L.) Schrad. (Colocynthis vulgaris Schrad.) & Cucurbitaceae & & & & & & $\bullet$ & $\bullet$ & \\
\hline Clinopodium nepeta (L.) Kuntze (Calamintha nepeta (L.) Savi) & Lamiaceae & & & & & & • & $\bullet$ & \\
\hline Crataegus monogyna Jacq. & Rosaceae & $\bullet$ & & & & & & & $\bullet$ \\
\hline Cuminum cyminum L. & Apiaceae & & $\bullet$ & $\bullet$ & & & & & \\
\hline Cynodon dactylon (L.) Pers. & Poaceae & & $\bullet$ & & & $\bullet$ & & & \\
\hline Daucus carota L. & Apiaceae & & & $\bullet$ & & & & & $\bullet$ \\
\hline $\begin{array}{l}\text { Dysphania ambrosioides (L.) Mosyakin \& Clemants } \\
\text { (Chenopodium ambrosioides L.) }\end{array}$ & Amaranthaceae & & & & $\bullet$ & $\bullet$ & & & \\
\hline Echinops spinosus L. & Asteraceae & $\bullet$ & & & & & $\bullet$ & & \\
\hline Elymus repens (L.) Gould (Agropyron repens (L.) P. Beauv.) & Poaceae & & & $\bullet$ & & & • & & \\
\hline Ephedra alata Decne. & Ephedraceae & & & & $\bullet$ & & & $\bullet$ & \\
\hline Eucalyptus globulus Labill. & Myrtaceae & & & $\bullet$ & & & $\bullet$ & & \\
\hline Ferula communis $\mathrm{L}$. & Apiaceae & & & & $\bullet$ & & & $\bullet$ & \\
\hline Ficus carica $\mathrm{L}$. & Moraceae & & & $\bullet$ & • & & & & \\
\hline Galium mollugo L. & Rubiaceae & $\bullet$ & & & & & $\bullet$ & & \\
\hline Globularia alypum $\mathrm{L}$. & Asteraceae & & & & - & $\bullet$ & & & \\
\hline Glycyrrhiza glabra L. & Fabaceae & $\bullet$ & & & $\bullet$ & & & & \\
\hline Gymnocarpos decander Forssk. & Caryophyllaceae & & & & & & $\bullet$ & $\bullet$ & \\
\hline $\begin{array}{l}\text { Hammada scoparia (Pomel) Iljin (Arthrophytum scoparium } \\
\text { (Pomel) Iljin) }\end{array}$ & Amaranthaceae & & $\bullet$ & & & $\bullet$ & & & \\
\hline Juglans regia $\mathrm{L}$. & Juglandaceae & & & $\bullet$ & & & • & & \\
\hline Juniperus communis L. & Cupressaceae & & & $\bullet$ & & & & & $\bullet$ \\
\hline Juniperus phoenicea L. & Cupressaceae & & & & • & & & • & \\
\hline Laurus nobilis L. & Lauraceae & & & & • & & & • & \\
\hline Lavandula angustifolia Mill. (Lavandula officinalis Chaix) & Lamiaceae & $\bullet$ & & & • & & & & \\
\hline Lavandula latifolia Medik. & Lamiaceae & & & $\bullet$ & & & & & $\bullet$ \\
\hline Lawsonia inermis $\mathrm{L}$. & Lythraceae & $\bullet$ & $\bullet$ & & & & & & \\
\hline Limoniastrum feei (Girard) Batt. & Plumbaginaceae & & & & $\bullet$ & & & $\bullet$ & \\
\hline Linum usitatissimum $\mathrm{L}$. & Linaceae & $\bullet$ & & & $\bullet$ & & & & \\
\hline Malva sylvestris $\mathrm{L}$. & Malvaceae & & & $\bullet$ & & & & & $\bullet$ \\
\hline Marrubium vulgaris L. & Lamiaceae & & & $\bullet$ & & & & & $\bullet$ \\
\hline Matricaria aurea (Loefl.) Sch.Bip. & Asteraceae & $\bullet$ & & & & & & & $\bullet$ \\
\hline Melissa officinalis L. & Lamiaceae & & & $\bullet$ & & & & & \\
\hline
\end{tabular}


Mentha arvensis $\mathrm{L}$.

Nerium oleander L.

Nigella sativa $\mathrm{L}$.

Opuntia ficus-indica (L.) Mill.

Origanum majorana L.

Parietaria officinalis L.

Peganum harmala $\mathrm{L}$.

Petroselinum crispum (Mill.) Fuss. (P. sativum Hoffm)

Phlomis bovei Noë

Pistacia atlantica Desf.

Pistacia lentiscus L.

Prunus dulcis (Mill.) D.A.Webb

Punica granatum L.

Reseda alba $\mathrm{L}$.

Retama raetam (Forssk.) Webb \& Berthel.

Rosmarinus officinalis $\mathrm{L}$.

Ruta chalepensis L.

Salix alba L.

Salvia officinalis L.

Silybum marianum (L.) Gaertner

Sinapis arvensis $\mathrm{L}$.

Stipa tenacissima L.

Syzygium aromaticum (L.) Merr. \& Perry

Tamarix gallica L.

Tetraclinis articulata (Vahl) Mast. (Thuja articulata Vahl)

Teucrium polium $\mathrm{L}$.

Thapsia garganica $\mathrm{L}$.

Thymelaea hirsuta (L.) Endl.

Thymus algeriensis Boiss. \& Reut.

Thymus vulgaris $\mathrm{L}$.

Trigonella foenum-graecum $\mathrm{L}$.

Urtica pilulifera $\mathrm{L}$.

Vaccinium myrtillus L.

Verbena officinalis L.

Vitis vinifera $\mathrm{L}$.

Zea mays L.

Zingiber officinale Roscoe

Ziziphus lotus (L.) Lam.

In total
Olea europaea L. (O. sylvestris Mill.)

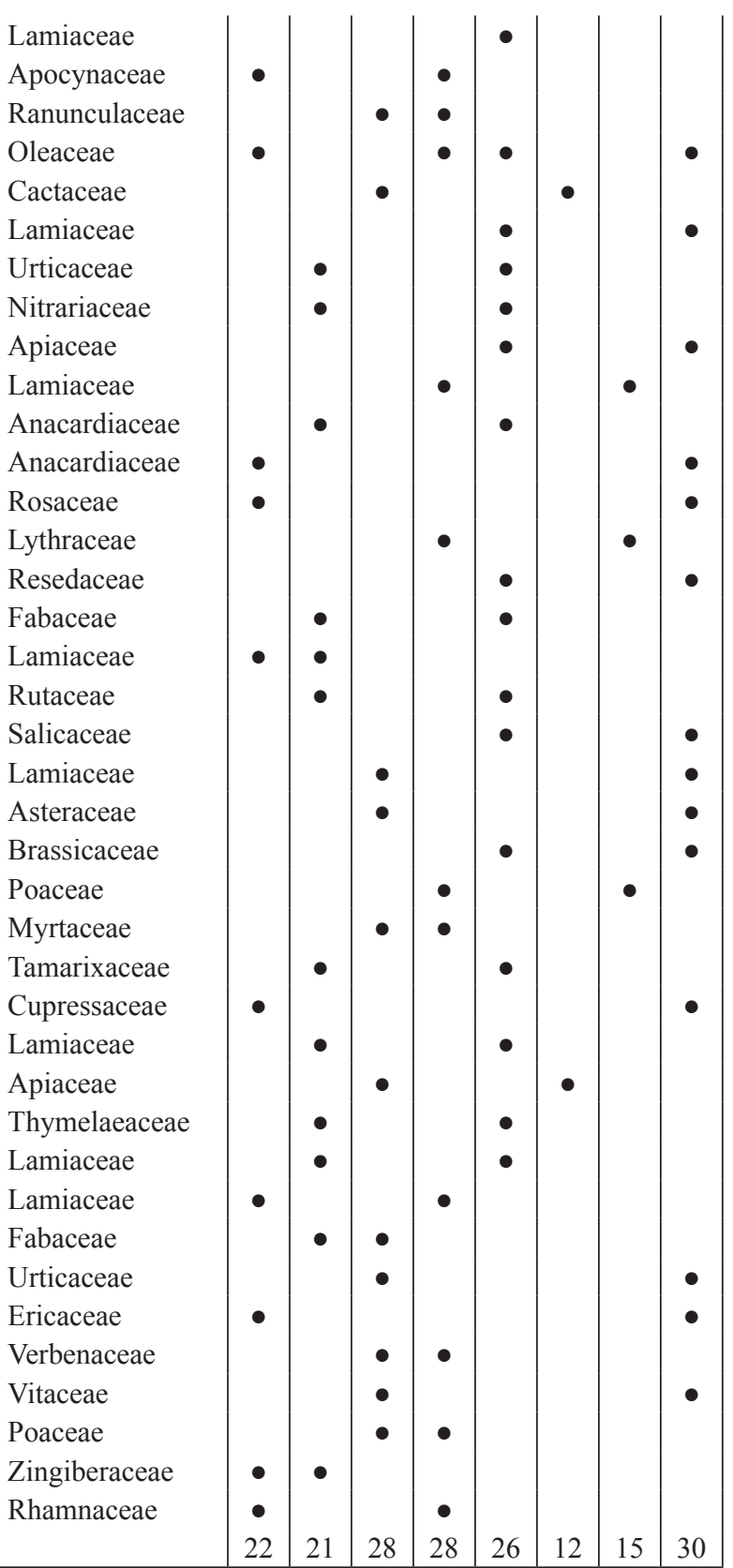

Explanation: * - according to The Plant List (2013) 